\title{
Erratum to: The Aerodynamics Development of the New Land Rover Discovery
}

Sébastien Chaligné, Ross Turner, and Adrian Gaylard

\author{
Erratum to: \\ Chapter "The Aerodynamics Development \\ of the New Land Rover Discovery" in: J. Wiedemann (ed.), \\ Progress in Vehicle Aerodynamics and Thermal Management, \\ https://doi.org/10.1007/978-3-319-67822-1_9
}

In the original version of the book, the title of Chapter 9 has been changed from "The Aerodynamics Development of the New Land Rover Discovery 5" to "The Aerodynamics Development of the New Land Rover Discovery". The erratum chapter and the book have been updated with the change.

The updated online version of this chapter can be found at https://doi.org/10.1007/978-3-319-67822-1_9 